\title{
Does Medical Disparity Exist While Treating Severe Mental Illness Patients with Acute Appendicitis in Emergency Departments? A Real-World Database Study
}

\author{
Shang-Kai Hung \\ Linkou Chang Gung Memorial Hospital \\ Hao-Wei Kou \\ Linkou Chang Gung Memorial Hospital \\ Kai-Hsiang Wu \\ Chiayi Chang Gung Memorial Hospital \\ Shou-Yen Chen \\ Linkou Chang Gung Memorial Hospital \\ Chih-Huang Li \\ Linkou Chang Gung Memorial Hospital \\ Chao-Wei Lee \\ Linkou Chang Gung Memorial Hospital \\ Yu-Yung Hung \\ Kaohsiung Veterans General Hospital \\ Shi-Ying Gao \\ Linkou Chang Gung Memorial Hospital \\ Po-Han Wu \\ Chiayi Chang Gung Memorial Hospital \\ Chiao-Hsuan Hsieh \\ Linkou Chang Gung Memorial Hospital \\ Chung-Hsien Chaou ( $\nabla$ m7088@cgmh.org.tw ) \\ Linkou Chang Gung Memorial Hospital
}

\section{Research Article}

Keywords: severe mental illness, acute appendicitis, health disparity, emergency department

Posted Date: February 15th, 2022

DOI: https://doi.org/10.21203/rs.3.rs-1253556/v2

License: (c) (i) This work is licensed under a Creative Commons Attribution 4.0 International License. Read Full License 


\section{Abstract \\ Background}

Patients with severe mental illness (SMI) have a shorter life expectancy and have been considered by the World Health Organization (WHO) as a vulnerable group. As the causes for this mortality gap are complex, clarification regarding the contributing factors is crucial to improving the health care of SMI patients. Acute appendicitis is one of the most common indicators of emergency surgery worldwide. A higher perforation rate has been found among psychiatric patients. This study aims to evaluate the differences in appendiceal perforation rate, emergency department (ED) management, in-hospital outcomes, and in-hospital expenditure among acute appendicitis patients with or without SMI via the use of a multi-centre database.

\section{Methods}

Relying on Chang Gung Research Database (CGRD) for data, we selectively used its data from January 1 st, 2007 to December 31st, 2017. The diagnoses of acute appendicitis and SMI were confirmed by combining ICD codes with relevant medical records. A non-SMI patient group was matched at the ratio of 1:3 by using the Greedy algorithm. The outcomes were appendiceal perforation rate, ED treatment, in-hospital outcome, and in-hospital expenditure.

\section{Results}

A total of 25,766 patients from seven hospitals over a span of 11 years were recruited; among them, 11,513 were excluded by criteria, with 14,253 patients left for analysis. SMI group was older ( 50.46 vs. 44.43 years, $p<0.01)$ and had a higher percentage of females (56.52 vs. $44.43 \%, p=0.01$ ) and Charlson Comorbidity Index. An analysis of the matched group has revealed that the SMI group has a higher unscheduled 72-hour revisit to ED (17.93 vs. 10.38\%, $p=$ 0.01). There was no significant difference in appendiceal perforation rate, ED treatment, in-hospital outcome, and inhospital expenditure.

\section{Conclusions}

Our study demonstrated no obvious differences in appendiceal perforation rate, ED management, in-hospital outcomes, and in-hospital expenditure among SMI and non-SMI patients with acute appendicitis. A higher unscheduled 72-hour ED revisit rate prior to the diagnosis of acute appendicitis in the SMI group was found. ED health providers need to be cautious when it comes to SMI patients with vague symptoms or unspecified abdominal complaints.

\section{Background}

Patients with severe mental illness (SMI) have a shorter life expectancy and have been considered by the World Health Organization (WHO) as a vulnerable group $(1,2)$. This mortality gap is estimated to shorten by 13 to 30 years among SMI patients, and $60 \%$ of this excess mortality is attributed to physical illness $(3,4)$. Even in countries with high-quality health care systems, the gap still exists and has, in fact, widened in recent decades (5). The causes for this mortality gap are complex and multifactorial. The patient-level factors include higher rates of suicide, accidental and violent death, poorer self-care, and higher occurrence of physical diseases; the socioeconomic-level factors include lower economic support, social stigma, and structural discrimination; and the health service-level factors include the iatrogenic adverse effect of some psychiatric medications, inequalities in physical comorbidity, and poorer access to emergent 
healthcare resources (6-8). To clarify the contributing factors, it is crucial to improve the health care of SMI patients and further narrow down the disparity gap.

Acute appendicitis is one of the most common indicators of emergency surgery worldwide, having an estimated 7-8\% lifetime risk (9). Although the specific pathophysiology of acute appendicitis is still unknown, inflammation secondary to direct luminal obstruction caused by a fecalith, lymphoid hyperplasia, or impacted stool is considered a major trigger. Given the variable presentations of acute appendicitis, the diagnostic values of clinical symptoms and signs are low. The most commonly used image modality in adult patients is the Computed Tomography (CT) scan. Surgical intervention is the cornerstone of treatment, and delay in management is associated with increased perforation rates (10). Due to the high incidence of acute appendicitis and the effectiveness of surgical interventions, appendectomy is considered the essential surgical service for basic human rights and is an indicator to evaluate health disparities (11, 12).

Earlier literature found a higher appendiceal perforation rate among vulnerable groups and considered the phenomenon as a disparity $(13,14)$. It is unclear whether the disparity still exists within the SMI patient population and what potential factors contribute to this phenomenon. This study aims to evaluate the differences in appendiceal perforation rate, emergency department (ED) management, in-hospital outcomes, and in-hospital expenditure experienced by acute appendicitis patients with or without SMI via the use of a multi-centre database.

\section{Methods}

\subsection{Data source}

We obtained our data from the Chang Gung Research Database (CGRD), the largest multi-institutional electronic medical records (EMR) collection in Taiwan. CGRD collects data from seven Chang Gung Memorial Hospitals (CGMH), including two tertiary medical centres, two regional hospitals, and three district hospitals. CGMH has a 10,050 beds capacity and admits more than a million patients each year (15). According to government statistics, there were over 500,000 ED visits to CGMH in 2015 and CGMH annually receives 11.5\% of the National Health Insurance budget in Taiwan (16). The basic architecture for CGRD includes clinical, epidemiological, laboratory, nursing, and disease categories, and cancer registry data for inpatient, outpatient, and emergency patients. The CGRD has been collecting deidentified data on the current and previous health conditions of patients by using the International Classification of Diseases, Ninth Revision, Clinical Modification (ICD-9-CM) codes before 2016 and using ICD-10-CM codes afterwards (17).

\subsection{Study population}

The study subjects were selected based on the CGRD data from January 1st, 2007 to December 31st, 2017. The diagnoses of acute appendicitis were confirmed by the ICD codes in discharge medical records combined with the national health insurance declarations data. Relevant diagnostic ICD codes identified the diagnoses of SMI for schizophrenia, bipolar disorder, or major depressive disorder by the psychiatrist at least once before the diagnosis of acute appendicitis. The exclusion criteria were below 18 years of age, not admitted through ED, and incomplete medical records. The relevant ICD codes for acute appendicitis and SMI are listed in Table 1. 
Table 1

ICD codes for inclusion criteria.

\begin{tabular}{|lll|}
\hline \multicolumn{2}{|c|}{ ICD-9-CM code } & ICD-10-CM code \\
\hline \multicolumn{2}{|l|}{ Acute Appendicitis } & \\
\hline Perforation & $540.0 ; 540.1$ & K352; K353 \\
\hline Non-perforation & $541 ; 542$ & K35; K3580; K3589; K36; K37 \\
\hline SMl & & \\
\hline Depression & $296.20-26 ; 296.30-36,296.82,298.0$ & F32.0-5; F32.9; F33.0-4; F33.9; F32.8 \\
\hline Schizophrenia & $295 ; 297 ; 298.3-4 ; 298.9$ & F20.0-3; F20.5; F20.8-9; F25.0-1; F25.8-9 \\
\hline Bipolar disorder & $296.00-16 ; 296.40-81 ; 296.89-99 ; 298.1$ & F30.1-4; F30.8-9; F31.0-9; F28 \\
\hline asMl, severe mental illness & \\
\hline
\end{tabular}


Table 2

Patient characteristics for overall, non-matched and matched groups.

\begin{tabular}{|c|c|c|c|c|c|c|c|}
\hline \multirow[t]{2}{*}{ Variable } & \multirow{2}{*}{$\begin{array}{l}\text { Overall } \\
(\mathrm{N}=14253)\end{array}$} & \multicolumn{3}{|l|}{ Non-match } & \multicolumn{3}{|c|}{ Matched by age and gender $(1: 3)$} \\
\hline & & $\begin{array}{l}\text { SMl }^{\mathrm{a}} \\
(\mathrm{N}=184)\end{array}$ & $\begin{array}{l}\text { Non-SMI } \\
(\mathrm{N}=14069)\end{array}$ & $\begin{array}{l}\mathrm{p} \\
\text { value }\end{array}$ & $\begin{array}{l}\text { SMI } \\
(\mathrm{N}=184)\end{array}$ & $\begin{array}{l}\text { Non-SMI } \\
(\mathrm{N}=559)\end{array}$ & $\begin{array}{l}\mathrm{p} \\
\text { value }\end{array}$ \\
\hline Age (year) & $44.51 \pm 17.50$ & $50.46 \pm 16.06$ & $44.43 \pm 17.50$ & $<0.01 *$ & $50.46 \pm 16.06$ & $50.52 \pm 16.01$ & 0.96 \\
\hline Female & $\begin{array}{l}6696 \\
(46.98)\end{array}$ & $104(56.52)$ & $\begin{array}{l}6592 \\
(46.85)\end{array}$ & $0.01 *$ & $104(56.52)$ & $318(56.89)$ & 0.99 \\
\hline \multicolumn{8}{|l|}{ Categories of SMI } \\
\hline Depression & $118(64.13)$ & $118(64.13)$ & - & - & $118(64.13)$ & - & - \\
\hline Schizophrenia & $51(27.72)$ & $51(27.72)$ & - & - & $51(27.72)$ & - & - \\
\hline Bipolar disorder & $15(8.15)$ & $15(8.15)$ & - & - & $15(8.15)$ & - & - \\
\hline \multicolumn{8}{|l|}{ Comorbidities } \\
\hline $\begin{array}{l}\text { Cardiovascular } \\
\text { disease }\end{array}$ & $1040(7.30)$ & $39(21.20)$ & $1001(7.11)$ & $<0.01^{\star}$ & $39(21.20)$ & $52(9.30)$ & $<0.01 *$ \\
\hline $\begin{array}{l}\text { Cerebrovascular } \\
\text { disease }\end{array}$ & $1246(8.74)$ & $42(22.83)$ & $1204(8.56)$ & $<0.01^{\star}$ & $42(22.83)$ & 62 (11.09) & $<0.01$ * \\
\hline $\begin{array}{l}\text { Pulmonary } \\
\text { disease }\end{array}$ & $\begin{array}{l}2118 \\
(14.86)\end{array}$ & 62 (33.70) & $\begin{array}{l}2056 \\
(14.61)\end{array}$ & $<0.01 *$ & 62 (33.70) & 94 (16.82) & $<0.01$ * \\
\hline Liver disease & $\begin{array}{l}2766 \\
(19.41)\end{array}$ & $80(43.48)$ & $\begin{array}{l}2686 \\
(19.09)\end{array}$ & $<0.01 *$ & $80(43.48)$ & $130(23.26)$ & $<0.01 *$ \\
\hline $\begin{array}{l}\text { Diabetes } \\
\text { mellitus }\end{array}$ & $\begin{array}{l}1700 \\
(11.93)\end{array}$ & 60 (32.61) & $\begin{array}{l}1640 \\
(11.66)\end{array}$ & $<0.01^{\star}$ & $60(32.61)$ & 80 (14.31) & $<0.01 *$ \\
\hline Renal disease & $1070(7.51)$ & 31 (16.85) & 1039 (7.39) & $<0.01^{\star}$ & 31 (16.85) & $47(8.41)$ & $<0.01 *$ \\
\hline Malignancy & 1195 (8.38) & $24(13.04)$ & 1171 (8.32) & $0.03^{*}$ & $24(13.04)$ & $53(9.48)$ & 0.22 \\
\hline AIDS $^{b}$ & $13(0.09)$ & $1(0.54)$ & $12(0.09)$ & 0.16 & $1(0.54)$ & $0(0)$ & 0.25 \\
\hline $\mathrm{CCl}^{\mathrm{C}} 1-2$ & $\begin{array}{l}10432 \\
(73.19)\end{array}$ & $90(48.91)$ & $\begin{array}{l}10342 \\
(73.51)\end{array}$ & $<0.01 *$ & $90(48.91)$ & $369(66.01)$ & $<0.01^{*}$ \\
\hline $\mathrm{CCl} 3-4$ & $\begin{array}{l}225 \\
7(15.84)\end{array}$ & 50 (27.17) & $\begin{array}{l}2207 \\
(15.69)\end{array}$ & $<0.01 *$ & $50(27.17)$ & $111(19.86)$ & $<0.01 *$ \\
\hline $\mathrm{CCl} \geqq 5$ & $\begin{array}{l}1564 \\
(10.97)\end{array}$ & $44(23.91)$ & $1520(10.8)$ & $<0.01 *$ & $44(23.91)$ & 79 (14.13) & $<0.01 *$ \\
\hline \multicolumn{8}{|c|}{ Count data are expressed as number (percentage) and continuous values are expressed as mean \pm SD. } \\
\hline \multicolumn{8}{|c|}{ asMI, severe mental illness. ${ }^{\text {b}}$ AIDS, acquired immune deficiency syndrome. ${ }^{c}$ Charlson Comorbidity Index } \\
\hline$\star_{p} p<0.05$ & & & & & & & \\
\hline
\end{tabular}


Table 3

Vital signs, laboratory test, operative methods, ED treatment and hospital outcomes for matched group

\begin{tabular}{|c|c|c|c|}
\hline Variable & $\begin{array}{l}\text { SMl }^{\mathrm{a}} \\
(\mathrm{N}=184)\end{array}$ & $\begin{array}{l}\text { Non-SMI } \\
(\mathrm{N}=559)\end{array}$ & $\mathrm{p}$ value \\
\hline Triage $^{\dagger}$ & & & 0.91 \\
\hline 1 & $1(0.54)$ & $3(0.54)$ & \\
\hline 2 & $24(13.04)$ & $66(11.81)$ & \\
\hline 3 & $153(83.15)$ & $464(83.01)$ & \\
\hline 4 & $6(3.26)$ & $25(4.47)$ & \\
\hline 5 & $0(0)$ & $1(0.18)$ & \\
\hline \multicolumn{4}{|l|}{ Vital signs in triage } \\
\hline $\mathrm{GCS}^{b}$ & $14.95 \pm 0.53$ & $14.97 \pm 0.33$ & 0.56 \\
\hline Pulse Rate (times/min) & $94.07 \pm 19.68$ & $89.98 \pm 17.36$ & $0.01 *$ \\
\hline Systolic blood pressure (mmHg) & $136.43 \pm 27.45$ & $136.23 \pm 24.59$ & 0.92 \\
\hline Respiratory rate (times/min) & $18.60 \pm 1.52$ & $18.53 \pm 1.50$ & 0.57 \\
\hline Body temperature $\left({ }^{\circ} \mathrm{C}\right)$ & $37.03 \pm 1.06$ & $36.99 \pm 0.90$ & 0.66 \\
\hline \multicolumn{4}{|l|}{ Laboratory test } \\
\hline White cell count (1000/uL) & $13.37 \pm 4.98$ & $13.41 \pm 4.84$ & 0.93 \\
\hline Platelet (1000/uL) & $216.66 \pm 66.32$ & $224.26 \pm 69.74$ & 0.21 \\
\hline Prothrombin time (sec) & $4.94 \pm 5.04$ & $4.77 \pm 4.85$ & 0.84 \\
\hline $\mathrm{APTT}^{\mathrm{c}}(\mathrm{sec})$ & $30.78 \pm 5.85$ & $30.06 \pm 3.12$ & 0.48 \\
\hline$B U N^{d}(m g / d L)$ & $14.32 \pm 10.99$ & $14.91 \pm 12.31$ & 0.76 \\
\hline Creatinine (mg/dL) & $1.08 \pm 1.26$ & $0.97 \pm 0.95$ & 0.59 \\
\hline $\mathrm{Na}(\mathrm{mEq} / \mathrm{L})$ & $136.82 \pm 3.83$ & $137.68 \pm 3.11$ & $0.03^{\star}$ \\
\hline $\mathrm{K}(\mathrm{mEq} / \mathrm{L})$ & $3.75 \pm 0.48$ & $3.79 \pm 0.42$ & 0.51 \\
\hline $\operatorname{ALT}^{\mathrm{e}}(\mathrm{U} / \mathrm{L})$ & $28.86 \pm 18.60$ & $26.14 \pm 18.06$ & 0.17 \\
\hline
\end{tabular}

Count data are expressed as number (percentage) and continuous values are expressed as mean \pm SD. aSMI, severe mental illness. ${ }^{b}$ GCS, Glasgow Coma Scale. ${ }^{\mathrm{c} A P T T}$, Activated partial thromboplastin time. ${ }^{d} B U N$, blood urea nitrogen. ${ }^{e} A L T$, alanine aminotransferase. ${ }^{f} C R P, C$-reactive protein.

${ }^{g} E D$, emergency department. ${ }^{\mathrm{h}} \mathrm{CU}$, intensive care unit. 'TWD, taiwan dollar †Five-Level Taiwan Triage and Acuity Scale.

${ }^{*} \mathrm{p}<0.05$ 


\begin{tabular}{|c|c|c|c|}
\hline Variable & $\begin{array}{l}\text { SMl }^{\mathrm{a}} \\
(\mathrm{N}=184)\end{array}$ & $\begin{array}{l}\text { Non-SMI } \\
(\mathrm{N}=559)\end{array}$ & $\mathrm{p}$ value \\
\hline Sugar (mg/dL) & $127.41 \pm 45.76$ & $126.01 \pm 36.97$ & 0.80 \\
\hline $\mathrm{CRP}^{f}(\mathrm{mg} / \mathrm{L})$ & $74.74 \pm 101.32$ & $67.40 \pm 83.63$ & 0.42 \\
\hline Operative methods & & & 0.45 \\
\hline Laparotomy & $60(34.48)$ & $209(39.66)$ & \\
\hline Laparoscopy & $99(56.90)$ & $272(51.61)$ & \\
\hline Other & $15(8.62)$ & $46(8.73)$ & \\
\hline Appendiceal perforation & $67(36.41)$ & $191(34.17)$ & 0.64 \\
\hline Unscheduled 72-hr ED revisit & 33 (17.93) & $58(10.38)$ & $0.01 *$ \\
\hline \multicolumn{4}{|l|}{ EDg treatment } \\
\hline Analgesics & $102(55.43)$ & 293(52.42) & 0.53 \\
\hline Opioid analgesics & $21(20.59)$ & $92(31.40)$ & 0.05 \\
\hline Non-opioid analgesics & $81(79.41)$ & $201(68.60)$ & 0.05 \\
\hline Time to 1 st order (min) & $18.27(11.55)$ & $18.09(11.62)$ & 0.87 \\
\hline Time to 1 st antibiotics (min) & 161.01 (105.66) & $170.31(136.38)$ & 0.37 \\
\hline Time to 1 st antibiotics (min) & $161.01(105.66)$ & $170.31(136.38)$ & 0.37 \\
\hline Time to CT scan (min) & $122.90(137.63)$ & $126.57(155.78)$ & 0.80 \\
\hline Time to surgical consultation (min) & $161.88(177.50)$ & $138.60(146.37)$ & 0.13 \\
\hline \multicolumn{4}{|l|}{ In-hospital outcome } \\
\hline Admission day & $7.11 \pm 5.96$ & $6.32 \pm 4.43$ & 0.11 \\
\hline ICU h admission & $4(2.19)$ & $10(1.82)$ & 0.48 \\
\hline In-hospital mortality & $0(0)$ & $0(0)$ & - \\
\hline In-hospital expenditure (TWD') & $51018.07(38269.71)$ & $45644.66(35165.19)$ & 0.08 \\
\hline \multicolumn{4}{|c|}{ Count data are expressed as number (percentage) and continuous values are expressed as mean \pm SD. } \\
\hline \multicolumn{4}{|c|}{ asMI, severe mental illness. ${ }^{\text {b}} \mathrm{GCS}$, Glasgow Coma Scale. ${ }^{\mathrm{C}} \mathrm{APTT}$, Activated partial thromboplastin time. } \\
\hline \multicolumn{4}{|c|}{${ }^{\mathrm{d}} \mathrm{BUN}$, blood urea nitrogen. ${ }^{\mathrm{e}} \mathrm{ALT}$, alanine aminotransferase. ${ }^{\mathrm{f}} \mathrm{CRP}, \mathrm{C}$-reactive protein. } \\
\hline \multicolumn{4}{|c|}{${ }^{g} E D$, emergency department. ${ }^{h} I C U$, intensive care unit. 'TWD, taiwan dollar } \\
\hline \multicolumn{4}{|c|}{ †Five-Level Taiwan Triage and Acuity Scale. } \\
\hline$*_{p}<0.05$ & & & \\
\hline
\end{tabular}

\subsection{Study outcomes and covariates}


Patients in the CGRD who were hospitalized through ED under the diagnosis of acute appendicitis were identified. The outcomes were appendiceal perforation rate, ED treatment, in-hospital outcome, and in-hospital expenditure. ED treatment consisted of analgesics usage, opioid analgesics, and non-opioid analgesics usage, and time from triage to first order, time from triage to first antibiotics administration, time from triage to receive CT scan, and time from triage to surgical consultation. The in-hospital outcome consisted of admission day, ICU admission, and in-hospital mortality. Appendiceal perforation has been identified as ICD-9-CM codes 540.0 and 540.1 or ICD-10-CM codes K35.2 and K35.3. Relevant ICD codes for analgesics, including opioid and non-opioid analgesics, have been detailed in Table 1. In-hospital mortality has been defined as mortality during the hospitalization by any etiology. The in-hospital expenditure was extracted from national health insurance declarations data. The covariates include demographic data, triage data, vital signs during ED stay, laboratory data, Charlson Comorbidity Index (CCl), operative methods, and unscheduled 72-hour revisit before the diagnosis of acute appendicitis. $\mathrm{CCl}$ is calculated based on the sum of weighted diagnoses, including several comorbidities (18). We determined the CCI score of patients based on there being two or more OPD visits with the same diagnosis in one year. CCI scores were categorized into three grades: mild, with CCI scores of 1-2; moderate, with $\mathrm{CCl}$ scores of $3-4$; and severe, with $\mathrm{CCl}$ scores $\geqq 5$ (19).

\subsection{Statistical analysis}

The continuous variables are presented as mean (SD), and the categorical variables are presented as count (\%). Given the large gap in the numbers of patients between the two groups, we utilized a matched case-control study design. A non-SMI patient group was matched at a ratio of 1:3 by using the Greedy algorithm (20). The variables included in the matching process were age ( \pm 5 years) and gender. We compared the continuous variables between the two independent groups by using the Student's t-test and compared the categorical variables between the two independent groups by using the Chi-square test. The statistical analysis is done using SAS version 9.4. A p-value of less than 0.05 is considered statistically significant. The work has been reported in line with the Strengthening The Reporting of Observational Studies in Epidemiology (STROBE) criteria (21).

\subsection{Ethical approval}

This study was approved by the Chang Gung Medical Foundation Institutional Review Board (IRB: 202001785B0), waiving the need for obtaining the consent of the study participants.

\section{Results}

\subsection{Patient characteristics}

A total of 25,766 patients from seven hospitals over a span of 11 years were recruited;of these, 11,513 were excluded by criteria, with 14,253 patients left for analysis. The recruitment flowchart is summarized in Figure 1.The mean age of the participants is $44.51 \pm 17.50$ (years). Of all the participants, $46.98 \%$ were female.In the SMI group, $64.13 \%$ of the patients had depression, $27.72 \%$ had schizophrenia, and $8.15 \%$ had bipolar disorder. When the patient demographics and medical history of both the groups were compared, we found theSMI group to be older (50.46 vs. 44.43 years, $p<0.01$ ) and have a higher percentage of females (56.52 vs. $44.43 \%, \mathrm{p}=0.01$ ). Comorbidities including cardiovascular disease ( 21.20 vs. $7.11 \%, p<0.01)$, cerebrovascular disease ( 22.83 vs. $8.56 \%, p<0.01)$, pulmonary disease $(33.70$ vs. $14.61 \%, p$ $<0.01$ ), liver disease (43.48 vs. $19.09 \%, p<0.01)$, diabetes mellitus (32.61 vs. $11.66 \%, p<0.01)$, renal disease (16.85 vs. $7.39 \%, p<0.01$ ), and malignancy (13.04 vs. $8.32 \%, p=0.03$ ) had a higher prevalence in the SMI group. SMI group also had a higher percentage of patients placed in moderate to severe $\mathrm{CCl}$ stages $(\mathrm{p}<0.01)$. After matching with age and gender, comorbidities including cardiovascular disease ( 21.20 vs. $9.30 \%, p<0.01)$, cerebrovascular disease (22.83 vs. $11.09 \%, p=0.01)$, pulmonary disease (33.70 vs. $16.82 \%, p<0.01)$, liver disease (43.48 vs. $23.26 \%, p<0.01)$, diabetes 
mellitus (32.61 vs. $14.31 \%, p<0.01)$, and renal disease $(16.85$ vs. $8.41 \%, p<0.01)$ stillshoweda higher prevalence in the SMI group with a higher percentage ofpatients placed in moderate to severe CCI stages $(p<0.01)$. The above results were summarized in Table 2.

Further analysis ofthe matched group revealed SMI group to havea higher triage pulse rate (94.07 vs. $89.98 \mathrm{times} / \mathrm{min}$, $p=0.01$ ), lower sodium level (136.82 vs. $137.68 \mathrm{mEq} / \mathrm{L}, \mathrm{p}=0.03$ ) and higher unscheduled 72-hour revisit to ED (17.93 vs. $10.38 \%, p=0.01)$. ED management, including opioid and non-opioid analgesics prescription, time to first order, time to the first antibiotics treatment, time to receive CT scan, and time to surgical consultation,for the two groups had no significant difference. In-hospital expenditure and in-hospital outcomes, including admission day, ICU admission rate, and appendiceal perforation rate, for the two groups also had no significant difference. The above results were summarized in Table 3.

\section{Discussion}

To the best of our knowledge, this study is the first to evaluate the emergency department management, in-hospital outcomes, and in-hospital expenditure experiencedby acute appendicitis patients with or without severe mental illness. This real-world database study found no significant difference in appendiceal perforation rate between the SMI and nonSMI patients with acute appendicitis. ED management, in-hospital outcome, and in-hospital expenditure also showed no significant differences between these two groups.

Previous studies have found a higher appendiceal perforation rateamongvulnerable groups, including elderly, racial minority, immigrant, poor socioeconomic, and insurance statuspopulations, in comparison to the other groups (14, 2224). This correlation was also demonstrated in the case of psychiatric patients andconsidered to be an instance of medical disparity. Using the Taiwan national insurance health data of1997 to 2001,Tsay et al. published an article in 2007 provingthat SMI patientshave a 2.83 times higher risk of appendiceal perforation than non-SMI patients with acute appendicitis $(13,25,26)$. However, we found no significant difference in appendiceal perforationrate between the SMI and non-SMI groups in this study. The evolution of medical treatment may explain this improvement. The increased utility of diagnostic modalities, including CT scans of acute appendicitis in the past few years, eliminates the medical gap in SMI patients $(27,28)$. Besides, the national health insurance in Taiwan has shown a positive influence in narrowing down the financial gap and improving the outcomesprovided to vulnerable groups (29). The advantage ofa near $100 \%$ population coverage rate with comprehensive expenditure coverage may alleviate the obstacles ofmedical accessibility faced by patients with SMI $(30,31)$.

Previous studies adopted analgesic prescription rate as an indicator to evaluate treatment disparity and proved the existence of a lower prescription rate amongfemale and racial minoritiesduring acute pain management (32-34). We found no obvious differences in analgesic prescription ratesbetweenthe SMI and non-SMI groups. However,a trend of lower opioid analgesics prescription ratewas noticedamong SMI patients.Several randomized trials have demonstrated that opioid analgesic is safe and efficient in treating acute appendicitis patients $(35,36)$. Further, a previous study found a lower opioid prescription rate also among black paediatric children with acute appendicitis in the United States and considered this phenomenon asthat of treatment inequity(37). Although our study found no statistical significance amongthe two groups, the trend of lower opioid administration in SMI patients still needs further investigation. The waiting time for medical evaluation and treatment is also important to evaluate the potential disparities in ED. Previous studies have foundthat patients with mental illness experience a longer waiting time to see a physician in ED(38). To understand the medical management in ED more comprehensively, we analysedtime from triage to first order, time from triage to first antibioticsadministration, time from triage to receiving CT scan, and time from triage to surgical consultation in ED. None of the above variables showed differences between the SMI and non-SMI groups. 
Our study aligns with the prior research that proved SMI patients to have a higher prevalence of several physical comorbidities, including cardiovascular disease, cerebrovascular disease, pulmonary disease, liver disease, DM, and renal disease(39). Although SMI patients with acute appendicitis have a higher prevalence of comorbidities than the general population, we found no obvious differences in admission day, ICU admission, in-hospital mortality, and inhospital expenditure between the two groups. This may be because acute appendicitis is a relatively benign disease with extremely low postoperative major adverse effects and mortality rate. Even in patients with multiple comorbidities, the current management can treat effectively without excessive cost (40).

We founda higher rate of unscheduled 72-hour ED revisits prior to the diagnosis of acute appendicitis in the SMI group. This may be because of the following reasons. First, SMI patients have a higher emergency medical resource usage in the case of psychiatric or physical illness (41). Second, the higher unscheduled 72-hour ED revisits rate may associate with misdiagnosis for prior ED visits. The possible risk factors include lower pain perception,poorer communication of SMI patients, and diagnostic overshadowingof health providers (42). Diagnostic overshadowing, the misattribution of physical symptoms to mental illness, was proved toexist among ED health providers(43). Thesuperimposition of thisstigmatizing attitude by the cognitive impairment and excess negative symptoms of SMI patients may make it difficultto have a timely diagnosis (44). ED health providers have to be more cautious when it comes to SMI patients with vague symptoms or unspecified abdominal complaints, and multidisciplinary evaluation may benefit these vulnerablegroups (45).

\section{Limitations}

There are remaining limitations ofthis study. First, due to the nature of the database study, individual symptoms characteristics were not included. This hampered further analysis owing to the potential reasons of higher unscheduled 72-hr ED revisit, which may be a result of multi-factors. Second, although CGRD is one of the largest databases in Taiwan, we still missed the patients with SMI diagnoses or those who received appendectomies in other medical facilities. Third, there are many components of disparities in the medical field. Although we demonstrated the cardinal management and timeline in ED without there being any obvious difference among the SMI patients, further investigations on the overshadowing or stigmatizing attitudesof health providersare still needed.

\section{Conclusion}

Our study demonstrated no obvious differences in appendiceal perforation rate, ED management, in-hospital outcomes, and in-hospital expenditure betweenthe SMI and non-SMI patients with acute appendicitis. It found a higher unscheduled 72-hour ED revisit rate prior to the diagnosis of acute appendicitis in the SMI group. ED health providers need to be cautious of SMI patients with vague symptoms or unspecified abdominal complaints. There is a need for further investigation onthe other components of medical disparities, including the overshadowing effect.

\section{Declarations}

Ethics approval and consent to participate:This study was approved by the Chang Gung Medical Foundation Institutional Review Board (IRB: 202001785B0C601), waiving the need for obtaining the informed consent of the study participants. All methods were carried out in accordance with relevant regulations.

Prior Presentations: This research has not been presented previously.

Consent for publication: Not applicable. 
Availability of data and materials:The datasets generated and/or analyzed during the currentstudy are available from the corresponding author onreasonable request.

Competing interests: The corresponding author confirms on behalf of all authors that there have been no involvements that might raise the question of bias in the work reported or in the conclusions, implications, or opinions stated.

Funding:There is no funding to disclose

Authors' contributions: Conceptualization: SKH, HWK, YYH; Data Curation: SKH, PHW, CHH; Formal analysis: SYG, CHC; Methodology: SYC, CHL; Investigation: SKH, SYC, KHW; Resources: CHL, CWL; Supervision: CHC; Writing: SKH, HWK, $\mathrm{CHC}$

Acknowledgements:This research was supported by Chang-Gung Memorial Hospital. We are thankful to our colleagues who provided their expertise, which greatly assisted the research, although they may not agree with all the interpretations provided in this paper.

\section{References}

1. Chang CK, Hayes RD, Perera G, Broadbent MT, Fernandes AC, Lee WE, et al. Life expectancy at birth for people with serious mental illness and other major disorders from a secondary mental health care case register in London. PLoS One. 2011;6(5):e19590.

2. Funk M, Drew N, Freeman M, Faydi E, World Health O. Mental health and development : targeting people with mental health conditions as a vulnerable group / Michelle Funk ... [et al]. Geneva: World Health Organization; 2010.

3. Vreeland B. Bridging the gap between mental and physical health: a multidisciplinary approach. J Clin Psychiatry. 2007;68 Suppl 4:26-33.

4. Tiihonen J, Lönnqvist J, Wahlbeck K, Klaukka T, Niskanen L, Tanskanen A, et al. 11-year follow-up of mortality in patients with schizophrenia: a population-based cohort study (FIN11 study). The Lancet. 2009;374(9690):620-7.

5. Osby U, Correia N, Brandt L, Ekbom A, Sparén P. Time trends in schizophrenia mortality in Stockholm county, Sweden: cohort study. Bmj. 2000;321(7259):483-4.

6. Thornicroft G. Physical health disparities and mental illness: the scandal of premature mortality. Br J Psychiatry. 2011;199(6):441-2.

7. Reilly S, Olier I, Planner C, Doran T, Reeves D, Ashcroft DM, et al. Inequalities in physical comorbidity: a longitudinal comparative cohort study of people with severe mental illness in the UK. BMJ Open. 2015;5(12):e009010.

8. Hayes JF, Marston L, Walters K, King MB, Osborn DPJ. Mortality gap for people with bipolar disorder and schizophrenia: UK-based cohort study 2000-2014. Br J Psychiatry. 2017;211(3):175-81.

9. Stewart B, Khanduri P, McCord C, Ohene-Yeboah M, Uranues S, Vega Rivera F, et al. Global disease burden of conditions requiring emergency surgery. Br J Surg. 2014;101(1):e9-22.

10. Papandria D, Goldstein SD, Rhee D, Salazar JH, Arlikar J, Gorgy A, et al. Risk of perforation increases with delay in recognition and surgery for acute appendicitis. J Surg Res. 2013;184(2):723-9.

11. McQueen KA, Ozgediz D, Riviello R, Hsia RY, Jayaraman S, Sullivan SR, et al. Essential surgery: Integral to the right to health. Health Hum Rights. 2010;12(1):137-52.

12. Ingram ME, Calabro K, Polites S, McCracken C, Aspelund G, Rich BS, et al. Systematic Review of Disparities in Care and Outcomes in Pediatric Appendectomy. J Surg Res. 2020;249:42-9.

13. Tsay JH, Lee CH, Hsu YJ, Wang PJ, Bai YM, Chou YJ, et al. Disparities in appendicitis rupture rate among mentally ill patients. BMC Public Health. 2007;7:331. 
14. Ponsky TA, Huang ZJ, Kittle K, Eichelberger MR, Gilbert JC, Brody F, et al. Hospital- and patient-level characteristics and the risk of appendiceal rupture and negative appendectomy in children. Jama. 2004;292(16):1977-82.

15. Chang Gung Memorial Hospital International Medical Center- Overview 2022 [updated January 6, 2022. Available from: http://www.chang-gung.com/en/about.aspx?id=11\&bid=1.

16. Tsai MS, Lin MH, Lee CP, Yang YH, Chen WC, Chang GH, et al. Chang Gung Research Database: A multi-institutional database consisting of original medical records. Biomed J. 2017;40(5):263-9.

17. Shao SC, Lai EC, Huang TH, Hung MJ, Tsai MS, Yang YH, et al. The Chang Gung Research Database: Multiinstitutional real-world data source for traditional Chinese medicine in Taiwan. Pharmacoepidemiol Drug Saf. 2021;30(5):652-60.

18. Charlson ME, Pompei P, Ales KL, MacKenzie CR. A new method of classifying prognostic comorbidity in longitudinal studies: development and validation. J Chronic Dis. 1987;40(5):373-83.

19. Huang YQ, Gou R, Diao YS, Yin QH, Fan WX, Liang YP, et al. Charlson comorbidity index helps predict the risk of mortality for patients with type 2 diabetic nephropathy. J Zhejiang Univ Sci B. 2014;15(1):58-66.

20. Kosanke J, Bergstralh E. Match one or more controls to cases using the GREEDY algorithm. Rochester, MN: Mayo Clinic College of Medicine. 2004.

21. Skrivankova VW, Richmond RC, Woolf BAR, Yarmolinsky J, Davies NM, Swanson SA, et al. Strengthening the Reporting of Observational Studies in Epidemiology Using Mendelian Randomization: The STROBE-MR Statement. Jama. 2021;326(16):1614-21.

22. Hui TT, Major KM, Avital I, Hiatt JR, Margulies DR. Outcome of elderly patients with appendicitis: effect of computed tomography and laparoscopy. Arch Surg. 2002;137(9):995-8; discussion 9-1000.

23. Lin KB, Chan CL, Yang NP, Lai RK, Liu YH, Zhu SZ, et al. Epidemiology of appendicitis and appendectomy for the low-income population in Taiwan, 2003-2011. BMC Gastroenterol. 2015;15:18.

24. Braveman P, Schaaf VM, Egerter S, Bennett T, Schecter W. Insurance-related differences in the risk of ruptured appendix. N Engl J Med. 1994;331(7):444-9.

25. Nishihira Y, McGill RL, Kinjo M. Perforated appendicitis in patients with schizophrenia: a retrospective cohort study. BMJ Open. 2017;7(9):e017150.

26. Lin HR, Wang HC, Wang JH, Lu HH. Increased risk of perforated appendicitis in patients with schizophrenia and dementia: A population-based case-control study. Medicine (Baltimore). 2020;99(5):e18919.

27. Wagner M, Tubre DJ, Asensio JA. Evolution and Current Trends in the Management of Acute Appendicitis. Surg Clin North Am. 2018;98(5):1005-23.

28. Raptopoulos V, Katsou G, Rosen MP, Siewert B, Goldberg SN, Kruskal JB. Acute appendicitis: effect of increased use of CT on selecting patients earlier. Radiology. 2003;226(2):521-6.

29. Lin KB, Lai KR, Yang NP, Wu KS, Ting HW, Pan RH, et al. Trends and outcomes in the utilization of laparoscopic appendectomies in a low-income population in Taiwan from 2003 to 2011. Int J Equity Health. 2015;14:100.

30. Wu TY, Majeed A, Kuo KN. An overview of the healthcare system in Taiwan. London J Prim Care (Abingdon). 2010;3(2):115-9.

31. Wang SI, Yaung CL. Vertical equity of healthcare in Taiwan: health services were distributed according to need. Int $J$ Equity Health. 2013;12:12.

32. Guedj R, Marini M, Kossowsky J, Berde CB, Kimia AA, Fleegler EW. Racial and Ethnic Disparities in Pain Management of Children With Limb Fractures or Suspected Appendicitis: A Retrospective Cross-Sectional Study. Front Pediatr. 2021;9:652854. 
33. Wilson TT, Chou SC, Becker S, Schuur JD, Beaudoin F. Evaluation of sex disparities in opioid use among ED patients with sickle cell disease, 2006-2015. Am J Emerg Med. 2021;50:597-601.

34. Morden NE, Chyn D, Wood A, Meara E. Racial Inequality in Prescription Opioid Receipt - Role of Individual Health Systems. N Engl J Med. 2021;385(4):342-51.

35. Amoli HA, Golozar A, Keshavarzi S, Tavakoli H, Yaghoobi A. Morphine analgesia in patients with acute appendicitis: a randomised double-blind clinical trial. Emerg Med J. 2008;25(9):586-9.

36. Yuan Y, Chen JY, Guo H, Zhang Y, Liang DM, Zhou D, et al. Relief of abdominal pain by morphine without altering physical signs in acute appendicitis. Chin Med J (Engl). 2010;123(2):142-5.

37. Goyal MK, Kuppermann N, Cleary SD, Teach SJ, Chamberlain JM. Racial Disparities in Pain Management of Children With Appendicitis in Emergency Departments. JAMA Pediatr. 2015;169(11):996-1002.

38. Opoku ST, Apenteng BA, Akowuah EA, Bhuyan S. Disparities in Emergency Department Wait Time Among Patients with Mental Health and Substance-Related Disorders. J Behav Health Serv Res. 2018;45(2):204-18.

39. M DEH, Correll CU, Bobes J, Cetkovich-Bakmas M, Cohen D, Asai I, et al. Physical illness in patients with severe mental disorders. I. Prevalence, impact of medications and disparities in health care. World Psychiatry. 2011;10(1):52-77.

40. Sartelli M, Baiocchi GL, Di Saverio S, Ferrara F, Labricciosa FM, Ansaloni L, et al. Prospective Observational Study on acute Appendicitis Worldwide (POSAW). World J Emerg Surg. 2018;13:19.

41. Niedzwiecki MJ, Sharma PJ, Kanzaria HK, McConville S, Hsia RY. Factors Associated With Emergency Department Use by Patients With and Without Mental Health Diagnoses. JAMA Netw Open. 2018;1(6):e183528.

42. De Hert M, Cohen D, Bobes J, Cetkovich-Bakmas M, Leucht S, Ndetei DM, et al. Physical illness in patients with severe mental disorders. II. Barriers to care, monitoring and treatment guidelines, plus recommendations at the system and individual level. World Psychiatry. 2011;10(2):138-51.

43. Shefer G, Henderson C, Howard LM, Murray J, Thornicroft G. Diagnostic overshadowing and other challenges involved in the diagnostic process of patients with mental illness who present in emergency departments with physical symptoms-a qualitative study. PLoS One. 2014;9(11):e111682.

44. Sølvhøj IN, Kusier AO, Pedersen PV, Nielsen MBD. Somatic health care professionals' stigmatization of patients with mental disorder: a scoping review. BMC Psychiatry. 2021;21(1):443.

45. Navanandan N, Schmidt SK, Cabrera N, Topoz I, DiStefano MC, Mistry RD. Seventy-two-hour Return Initiative: Improving Emergency Department Discharge to Decrease Returns. Pediatr Qual Saf. 2020;5(5):e342.

\section{Tables}

Table 1. ICD codes for inclusion criteria. 


\begin{tabular}{|lll|}
\hline \multicolumn{2}{|c|}{ ICD-9-CM code } & ICD-10-CM code \\
\hline \multicolumn{2}{|l|}{ Acute Appendicitis } & \\
\hline Perforation & $540.0 ; 540.1$ & K352; K353 \\
\hline Non-perforation & $541 ; 542$ & K35; K3580; K3589; K36; K37 \\
\hline SMl $^{\text {a }}$ & & \\
\hline Depression & $296.20-26 ; 296.30-36,296.82,298.0$ & F32.0-5; F32.9; F33.0-4; F33.9; F32.8 \\
\hline Schizophrenia & $295 ; 297 ; 298.3-4 ; 298.9$ & F20.0-3; F20.5; F20.8-9; F25.0-1; F25.8-9 \\
\hline Bipolar disorder & $296.00-16 ; 296.40-81 ; 296.89-99 ; 298.1$ & F30.1-4; F30.8-9; F31.0-9; F28 \\
\hline
\end{tabular}

aSMI, severe mental illness

Table 2. Patient characteristics for overall, non-matched and matched groups. 


\begin{tabular}{|c|c|c|c|c|c|c|c|}
\hline \multirow[t]{2}{*}{ Variable } & \multirow{2}{*}{$\begin{array}{l}\text { Overall } \\
(\mathrm{N}=14253)\end{array}$} & \multicolumn{3}{|l|}{ Non-match } & \multicolumn{3}{|c|}{ Matched by age and gender $(1: 3)$} \\
\hline & & $\begin{array}{l}S M l^{a} \\
(N=184)\end{array}$ & $\begin{array}{l}\text { Non-SMI } \\
(\mathrm{N}=14069)\end{array}$ & $\begin{array}{l}p \\
\text { value }\end{array}$ & $\begin{array}{l}\text { SMI } \\
(N=184)\end{array}$ & $\begin{array}{l}\text { Non-SMI } \\
(\mathrm{N}=559)\end{array}$ & $\begin{array}{l}\mathrm{p} \\
\text { value }\end{array}$ \\
\hline Age (year) & $44.51 \pm 17.50$ & $50.46 \pm 16.06$ & $44.43 \pm 17.50$ & $<0.01^{*}$ & $50.46 \pm 16.06$ & $50.52 \pm 16.01$ & 0.96 \\
\hline Female & $\begin{array}{l}6696 \\
(46.98)\end{array}$ & $104(56.52)$ & $\begin{array}{l}6592 \\
(46.85)\end{array}$ & $0.01^{*}$ & $104(56.52)$ & $318(56.89)$ & 0.99 \\
\hline \multicolumn{8}{|l|}{ Categories of SMI } \\
\hline Depression & 118 (64.13) & 118 (64.13) & - & - & 118 (64.13) & - & - \\
\hline Schizophrenia & $51(27.72)$ & 51 (27.72) & - & - & $51(27.72)$ & - & - \\
\hline Bipolar disorder & $15(8.15)$ & $15(8.15)$ & - & - & $15(8.15)$ & - & - \\
\hline \multicolumn{8}{|l|}{ Comorbidities } \\
\hline $\begin{array}{l}\text { Cardiovascular } \\
\text { disease }\end{array}$ & $1040(7.30)$ & $39(21.20)$ & $1001(7.11)$ & $<0.01^{*}$ & $39(21.20)$ & $52(9.30)$ & $<0.01^{*}$ \\
\hline $\begin{array}{l}\text { Cerebrovascular } \\
\text { disease }\end{array}$ & $1246(8.74)$ & $42(22.83)$ & $1204(8.56)$ & $<0.01^{*}$ & $42(22.83)$ & 62 (11.09) & $<0.01^{*}$ \\
\hline $\begin{array}{l}\text { Pulmonary } \\
\text { disease }\end{array}$ & $\begin{array}{l}2118 \\
(14.86)\end{array}$ & 62 (33.70) & $\begin{array}{l}2056 \\
(14.61)\end{array}$ & $<0.01^{*}$ & $62(33.70)$ & $94(16.82)$ & $<0.01^{*}$ \\
\hline Liver disease & $\begin{array}{l}2766 \\
(19.41)\end{array}$ & $80(43.48)$ & $\begin{array}{l}2686 \\
(19.09)\end{array}$ & $<0.01 *$ & $80(43.48)$ & $130(23.26)$ & $<0.01^{*}$ \\
\hline $\begin{array}{l}\text { Diabetes } \\
\text { mellitus }\end{array}$ & $\begin{array}{l}1700 \\
(11.93)\end{array}$ & $60(32.61)$ & $\begin{array}{l}1640 \\
(11.66)\end{array}$ & $<0.01^{*}$ & $60(32.61)$ & 80 (14.31) & $<0.01^{*}$ \\
\hline Renal disease & $1070(7.51)$ & 31 (16.85) & 1039 (7.39) & $<0.01^{*}$ & $31(16.85)$ & $47(8.41)$ & $<0.01^{*}$ \\
\hline Malignancy & 1195 (8.38) & $24(13.04)$ & $1171(8.32)$ & $0.03^{*}$ & $24(13.04)$ & $53(9.48)$ & 0.22 \\
\hline AIDS $^{b}$ & $13(0.09)$ & $1(0.54)$ & $12(0.09)$ & 0.16 & $1(0.54)$ & $0(0)$ & 0.25 \\
\hline $\mathrm{CCl}^{\mathrm{C}} 1-2$ & $\begin{array}{l}10432 \\
(73.19)\end{array}$ & $90(48.91)$ & $\begin{array}{l}10342 \\
(73.51)\end{array}$ & $<0.01^{*}$ & $90(48.91)$ & 369 (66.01) & $<0.01^{*}$ \\
\hline $\mathrm{CCl} 3-4$ & $\begin{array}{l}225 \\
7(15.84)\end{array}$ & $50(27.17)$ & $\begin{array}{l}2207 \\
(15.69)\end{array}$ & $<0.01^{*}$ & $50(27.17)$ & 111 (19.86) & $<0.01^{*}$ \\
\hline $\mathrm{CCl} \geqq 5$ & $\begin{array}{l}1564 \\
(10.97)\end{array}$ & $44(23.91)$ & $1520(10.8)$ & $<0.01^{*}$ & $44(23.91)$ & 79 (14.13) & $<0.01^{*}$ \\
\hline
\end{tabular}

Count data are expressed as number (percentage) and continuous values are expressed as mean \pm SD.

${ }^{a}$ SMI, severe mental illness. ${ }^{b}$ AIDS, acquired immune deficiency syndrome. ${ }^{c}$ Charlson Comorbidity Index $* p<0.05$

Table 3 Vital signs, laboratory test, operative methods, ED treatment and hospital outcomes for matched group 


\begin{tabular}{|c|c|c|c|}
\hline Variable & $\begin{array}{l}\text { SMI }^{\mathrm{a}} \\
(\mathrm{N}=184)\end{array}$ & $\begin{array}{l}\text { Non-SMI } \\
(\mathrm{N}=559)\end{array}$ & $\mathrm{p}$ value \\
\hline Triage $^{\dagger}$ & & & 0.91 \\
\hline 1 & $1(0.54)$ & $3(0.54)$ & \\
\hline 2 & $24(13.04)$ & $66(11.81)$ & \\
\hline 3 & $153(83.15)$ & $464(83.01)$ & \\
\hline 4 & $6(3.26)$ & $25(4.47)$ & \\
\hline 5 & $0(0)$ & $1(0.18)$ & \\
\hline \multicolumn{4}{|l|}{ Vital signs in triage } \\
\hline $\mathrm{GCS}^{\mathrm{b}}$ & $14.95 \pm 0.53$ & $14.97 \pm 0.33$ & 0.56 \\
\hline Pulse Rate (times/min) & $94.07 \pm 19.68$ & $89.98 \pm 17.36$ & $0.01 *$ \\
\hline Systolic blood pressure (mmHg) & $136.43 \pm 27.45$ & $136.23 \pm 24.59$ & 0.92 \\
\hline Respiratory rate (times/min) & $18.60 \pm 1.52$ & $18.53 \pm 1.50$ & 0.57 \\
\hline Body temperature $\left({ }^{\circ} \mathrm{C}\right)$ & $37.03 \pm 1.06$ & $36.99 \pm 0.90$ & 0.66 \\
\hline \multicolumn{4}{|l|}{ Laboratory test } \\
\hline White cell count $(1000 / u L)$ & $13.37 \pm 4.98$ & $13.41 \pm 4.84$ & 0.93 \\
\hline Platelet (1000/uL) & $216.66 \pm 66.32$ & $224.26 \pm 69.74$ & 0.21 \\
\hline Prothrombin time (sec) & $4.94 \pm 5.04$ & $4.77 \pm 4.85$ & 0.84 \\
\hline APTT $^{\mathrm{c}}(\mathrm{sec})$ & $30.78 \pm 5.85$ & $30.06 \pm 3.12$ & 0.48 \\
\hline $\mathrm{BUN}^{\mathrm{d}}(\mathrm{mg} / \mathrm{dL})$ & $14.32 \pm 10.99$ & $14.91 \pm 12.31$ & 0.76 \\
\hline Creatinine $(\mathrm{mg} / \mathrm{dL})$ & $1.08 \pm 1.26$ & $0.97 \pm 0.95$ & 0.59 \\
\hline $\mathrm{Na}(\mathrm{mEq} / \mathrm{L})$ & $136.82 \pm 3.83$ & $137.68 \pm 3.11$ & $0.03^{*}$ \\
\hline $\mathrm{K}(\mathrm{mEq} / \mathrm{L})$ & $3.75 \pm 0.48$ & $3.79 \pm 0.42$ & 0.51 \\
\hline $\mathrm{ALT}^{\mathrm{e}}(\mathrm{U} / \mathrm{L})$ & $28.86 \pm 18.60$ & $26.14 \pm 18.06$ & 0.17 \\
\hline Sugar (mg/dL) & $127.41 \pm 45.76$ & $126.01 \pm 36.97$ & 0.80 \\
\hline $\mathrm{CRP}^{\mathrm{f}}(\mathrm{mg} / \mathrm{L})$ & $74.74 \pm 101.32$ & $67.40 \pm 83.63$ & 0.42 \\
\hline Operative methods & & & 0.45 \\
\hline Laparotomy & $60(34.48)$ & $209(39.66)$ & \\
\hline Laparoscopy & $99(56.90)$ & $272(51.61)$ & \\
\hline Other & $15(8.62)$ & $46(8.73)$ & \\
\hline Appendiceal perforation & $67(36.41)$ & $191(34.17)$ & 0.64 \\
\hline Unscheduled 72-hr ED revisit & $33(17.93)$ & $58(10.38)$ & $0.01^{*}$ \\
\hline
\end{tabular}




\begin{tabular}{|llll|}
\hline ED treatment & & & \\
\hline Analgesics & $102(55.43)$ & $293(52.42)$ & 0.53 \\
\hline Opioid analgesics & $21(20.59)$ & $92(31.40)$ & 0.05 \\
\hline Non-opioid analgesics & $81(79.41)$ & $201(68.60)$ & 0.05 \\
\hline Time to $1^{\text {st }}$ order (min) & $18.27(11.55)$ & $18.09(11.62)$ & 0.87 \\
\hline Time to $1^{\text {st }}$ antibiotics (min) & $161.01(105.66)$ & $170.31(136.38)$ & 0.37 \\
\hline Time to $1^{\text {st }}$ antibiotics (min) & $161.01(105.66)$ & $170.31(136.38)$ & 0.37 \\
\hline Time to CT scan (min) & $122.90(137.63)$ & $126.57(155.78)$ & 0.80 \\
\hline Time to surgical consultation (min) & $161.88(177.50)$ & $138.60(146.37)$ & 0.13 \\
\hline In-hospital outcome & & & 0.11 \\
\hline Admission day & $7.11 \pm 5.96$ & $6.32 \pm 4.43$ & 0.48 \\
\hline ICUh admission & $4(2.19)$ & $10(1.82)$ & - \\
\hline In-hospital mortality & $0(0)$ & $0(0)$ & 0.08 \\
\hline In-hospital expenditure (TWD $)$ & $51018.07(38269.71)$ & $45644.66(35165.19)$ & \\
\hline
\end{tabular}

Count data are expressed as number (percentage) and continuous values are expressed as mean \pm SD.

aSMI, severe mental illness. ${ }^{b}$ GCS, Glasgow Coma Scale. ${ }^{\mathrm{C}} \mathrm{APTT}$, Activated partial thromboplastin time.

${ }^{d} B U N$, blood urea nitrogen. ${ }^{e} \mathrm{ALT}$, alanine aminotransferase. ${ }^{f} \mathrm{CRP}, \mathrm{C}$-reactive protein.

${ }^{g} E D$, emergency department. ${ }^{h} I C U$, intensive care unit. 'TWD, taiwan dollar

†Five-Level Taiwan Triage and Acuity Scale.

${ }^{*} \mathrm{p}<0.05$

\section{Figures}




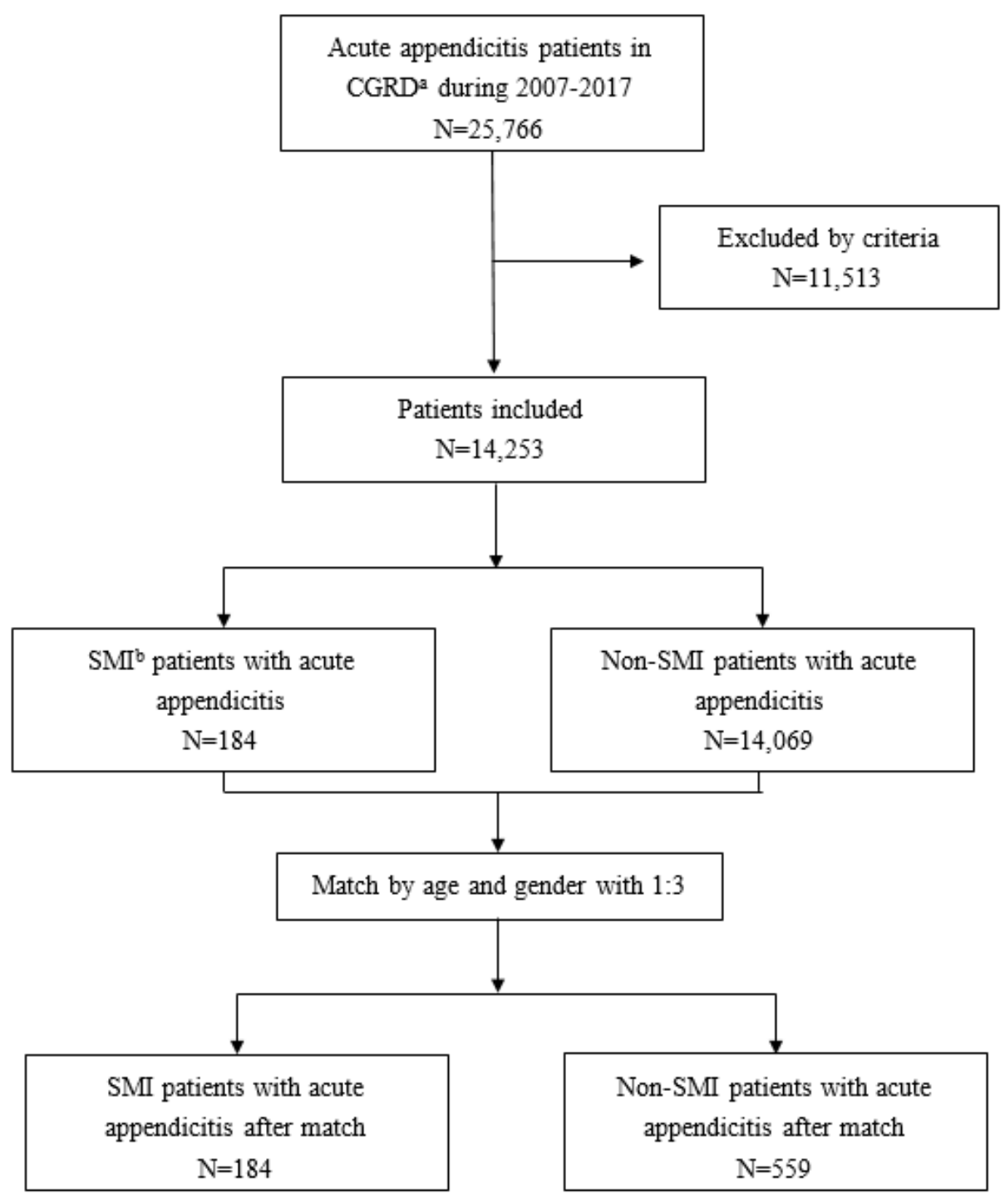

\section{Figure 1}

Flow chart of participants in cohort study.

aCGRD, Chang Gung Research Database.bSMI, severe mental illness.

\section{Supplementary Files}

This is a list of supplementary files associated with this preprint. Click to download.

- STROBEchecklist.docx 